\section{En massemorders barndom}

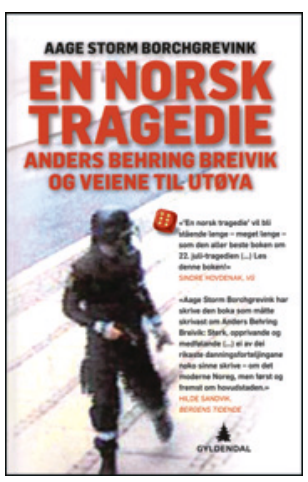

Aage Storm Borchgrevink

En norsk tragedie

Anders Behring Breivik og veiene til Utøya. 368 s, ill. Oslo: Gyldendal, 2012. Pris NOK 399 ISBN 978-82-05-42878-2

Forfatteren er seniorrådgiver i Helsingforskomiteen og har tidligere publisert romaner, noveller og sakprosa om konfliktene på Balkan og i Kaukasus. I denne boken skildrer han Anders Behring Breiviks livsløp fra barndom til ungdom, til han 33 år gammel blir massemorder. Borchgrevink bygger bl.a. på intervjuer med tidligere venner og bekjente av Breivik. Samtidig forteller han om bombingen av regjeringskvartalet og massakren på Utøya, der overlevendes beretninger gir et både følsomt og gripende bilde av det som skjedde 22. juli 2011.

Det meste har vi hørt før, men nytt er opplysningene om den omsorgssvikt gutten ble utsatt for i tidlige barneår. Da han var bare ett år, ble det skilsmisse mellom foreldrene. Faren var fraværende og kuttet kontakten med sønnen da han var 15 år gammel. Men det er mor skytset rettes mot. Hun var svingende i gemytt og hadde dels dødsønsker over sønnen, som hun fant krevende, klengete og vanskelig. Fire år gammel ble han så undersøkt ved Statens senter for barne- og ungdomspsykiatri, der man mente barnevernet må overta omsorgen for ham. Det skjedde ikke.

Kan man forstå hva som driver en ung mann til å ta livet av så mange på en ettermiddag? Til å begynne med får man inntrykk av at forfatteren betrakter omsorgssvikten i barndommen som én av mange brikker i årsakskomplekset, men på slutten vender han tilbake til barnepsykiatrien og argumenterer for barndomskonfliktene som den helt sentrale forklaringsfaktor. Ikke bare Breiviks senere hat og massedrap, men hans kvinneforakt og hans manifest kan ifølge forfatteren hovedsakelig forstås ut fra hans barndomstraumer. Det er nok for enkelt. Mange barn har opplevd omsorgssvikt ytterst få blir massemordere.

Borchgrevink er verken psykolog eller psykiater, men han har studert faglitteraturen og konsultert psykiatere. Vi leser om narsissisme og andre personlighetsforstyrrelser og det ikke helt klare moderne begrepet «mentalisering». Diagnosen fra Statens senter er «reaktiv tilknytningsforstyrrelse», som sjelden anvendes i dag. De inadekvate følelsesmessige reaksjonene viser seg vanligvis før 4-5-årsalderen og kommer gjerne til uttrykk når foreldrene reiser bort eller kommer tilbake. Frykt og vaktsomhet som ikke avdempes med trøst skal være karakteristisk, videre et dårlig forhold til barn på samme alder. Man regner at syndromet stort sett er et resultat av overgrep fra foreldrenes side.

Boken på knapt 400 sider er resultatet av et meget grundig arbeid fra forfatterens side. Borchgrevink skriver godt og innsiktsfullt, og de mange detaljene får oss ikke til å miste overblikket. Det bildet vi får av Breivik og hans miljø på Oslo vestkant er overbevisende. Men å referere fra taushetsbelagte legeopplysninger uten tillatelse fra hovedpersonen eller hans mor kan ikke forsvares.

\section{Einar Kringlen}

Psykiatrisk institutt

Universitetet i Oslo

\section{Fra innsiden}

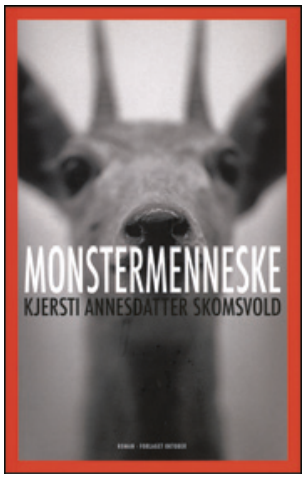

Kjersti Annesdatter Skomsvold Monstermenneske

580 s. Oslo: Forlaget Oktober, 2012

Pris NOK 379

ISBN 978-82-495-1057-3

Her făr vi presentert en sykdomsopplevelse som er ganske typisk ved diagnosen $\mathrm{ME}$, men det er vanskelig å se hvor Kjersti slutter og konsulentene overtar. Vanlige kognitive forandringer, som tap av tidsoppfatning, opplevelse av selv og tilhørighet til menneskene, burde overflødiggjøre litterære grep, så fra et medisinsk synspunkt er det litt synd. Sykdommen får likevel komme usminket frem sammen med den nærmest obligatoriske eksistensielle krisen som medfølger. Bokens sentrale tema er imidlertid selve skriveprosessen og hvordan hun bruker den til å gjenvinne og gjenskape en identitet.

Det fremkommer at forfatteren har holdt et altfor høyt aktivitetsnivå etter kyssesyken. Hun lærer aktivitetsavpasning slik det ikke skal gjøres. Postviral asteni etter mononukleose kan erfaringsmessig gi et meget langtrukkent og komplisert sykdomsforløp. I hvilken grad det slår over i ME, er lite kjent, og historien bidrar ikke til å opplyse saken. Symptombildet og sykdomsutviklingen presenteres i drypp, men ufullstendig.

Kjersti blir forlatt av ungdomskjæresten når den forventede bedringen uteblir. Det blir vanskelig for henne å skille mellom kjærlighetssorgen og nedturene som følger av sykdommens svingninger. Utydelig for leseren blir også grensene mellom en tilbakevendende følelse av å skulle dø, håpløshet som følge av lange perioder i relativ isolasjon, intense og uberegnelige kroppslige plager og det vi får inntrykk av at er en sykdomsutløst angst.

Historien utfolder seg ukronologisk og uten noen skikkelig presentasjon av persongalleriet, hvilket synes å avspeile den malstrømmen hovedpersonen befinner seg i, der hun stadig oftere virvles opp til overflaten. Det er her skrivingen kommer inn, som et hjelpemiddel $i$ en indre dialog. Mange tyr til en dagbok eller blogg, men Kjersti har en større ambisjon. Hun vil skrive bok og være en litterat blant litterater, med en tilhørighet utenfor sykdommen.

Bokambisjonene gir distanse til den usikkerheten for fremtiden som skapes av å leve i en slik vedvarende akuttilstand. Skrivingen gir også mestringsfølelse og dermed bedre funksjonsevne. Men det er tøft når en 25-åring bestemmer seg for ikke å ta tilbake ham som dumpet henne da hun var syk. Nå vet hun at det vil kunne skje igjen. Nettopp fordi hun går så helhjertet inn i en-til-en-relasjoner, velger hun å redde seg selv først: «[...] forestiller meg hvordan jeg er fanget i et skrivetårn, tjuesju engler binder meg fast, og jeg er gal etter å få oppleve kjærlighet, men jeg må bare skrive i stedet.»

En humoristisk fortellerstemme gjør boken lettlest, alvoret til tross. Fra en litterært mindre interessant, men medisinsk relevant synsvinkel, blir det mye forlenget pubertet med kroppsfiksering og relasjonsbygging, som øyensynlig også bidrar til å undertrykke og etter hvert viske ut sykdommen. Hun oppnår et stadig høyere funksjonsnivå, men det er uvisst hvor frisk hun egentlig blir.

Med tanke på den benektningen av tilstanden som er vanlig blant barn og unge i ettertid, ville en annen tittel muligens hatt større appell. Bokens ytre er ellers behagelig for øyet med sin symboltunge illustrasjon.

Sidsel Kreyberg

Registeret for ME/PVFS (G93.3) i Norge Oslo 